\title{
FACTORS AFFECTING THE USE OF FISCALLY PROTECTIONISM INSTRUMENTS USED IN INTERNATIONAL TRADE*
}

\author{
Göksel KARAŞ $^{1} \quad$ Ufuk SELEN ${ }^{2}$
}

\begin{abstract}
Depending on the developments in the world, the presence of the state in the economy also changes. In the economic welfare periods, minimal state view is adopted, while in the periods of contraction and crisis the interventionist state view is adopted. The international trade system is also affected from this. In the periods when the minimal state view was adopted, the free trade system was the dominant paradigm and in the periods when the interventionist state view was adopted, protectionism was the dominant paradigm. These developments are shaped by the nation-states, which are the hegemonic power of the period. Such countries act with the discourse of "insinde Keynes outside Smith", and on the one hand, do not hesitate to apply protectionist policies while making liberalization discourses around the world. Although the international trade system is based on the free trade system, protectionist policies are also implemented. In this context, protectionist instruments which allow World Trade Organization to use under certain constraints are used. These instruments can be grouped into two groups as protectionist instruments that are fiscally and non-fiscally qualified in terms of the effects they create in public finances. In this study, the factors affecting the use of fiscally protectionist instruments in international trade are analyzed on the basis of countries by negative binomial regression analysis. In this study, the data set of 16 countries covering the years 1995-2016 is used. While fiscally protection instruments are used for individual interests instead of macroeconomic targets by developed countries, they are predominantly used for macroeconomic targets by the low and middle-income countries.
\end{abstract}

Keywords: Free Trade, Protectionism, Fiscally Protectionism Instruments, Negative Binomial Regression Analysis JEL Code: F13, O24, P45.

\section{Introduction}

Over time, the legitimacy of state intervention in the market is discussed, depending on the conjunctural situation, and while market economy is prevailing policy in the periods of expansion and prosperity, interventionist policies is prevailing policy in the periods of contraction and crisis. When this situation is evaluated in terms of international trade, free trade system is applied in the periods of expansion and prosperity, and protectionism is applied in the periods of contraction and crisis. Therefore, although the international trade system is developed on the basis of free trade system, it is seen that the protectionist policies are applied in this system intensively.

The World Trade Organization (WTO) is responsible for establishing and implementing the rules and standards to be followed in international trade. The WTO states that countries should not resort to protectionist policies with a few exceptions in order to liberalize world trade. However, countries are able to implement protectionist policies in order to protect national

\footnotetext{
* This study is composed of the PhD thesis prepared by the Bursa Uludag University Social Sciences Institute, Department of Public Finance.

1 Res. Asst. Dr., Kütahya Dumlupınar University, Faculty of Economics and Administrative Sciences, Department of International Trade and Finance, goksel.karas@dpu.edu.tr (Corresponding Author)

2 Assoc. Prof., T.C. Bursa Uludağ University, Faculty of Economics and Administrative Sciences, Department of Public Finance, uselen@uludag.edu.tr
} 
security, economic development, protection of small industries, increase employment levels, improve trade volume, increase international competitiveness and prevent unfair competition. Protectionist policies can be implemented with the protection policy instruments permitted by the WTO. Although these instruments are classified in different ways in the literature, they can be classified as fiscally and non-fiscally instruments in terms of the effects of the countries on public finances in accordance with the purpose of the study.

In this study, it was aimed to determine the factors affecting the use of anti-dumping, countervailing duty and safeguard measures which are fiscally protectionism instruments of WTO members. In this study, negative binomial regression analysis constitutes by using the fiscally protectionism instruments which includes anti-dumping duties, countervailing duties and safeguard measures as dependent variable and macroeconomic variables such as growth rate, the share of imports in GDP, the ratio of imports to imports, exchange rate and unemployment rate as independent variables between the years of $1995-2016$ for the 16 countries that use the most fiscally protectionism instruments in the world.

\section{Market Economy and The International Trade System Relationship}

Market economy is a volatility of voluntary exchanges, where the division of labor and private ownership exist, free prices, contracting and freedom of enterprise exist, the cost of acquiring information is low, competition in the market and decentralized decision-making is valid, private enterprise is based (Akalın, 2002: 90). The market economy is mainly aimed at cost minimization. In the market economy, where the cost minimization is aimed, the costs are minimized and the needs are met at the highest level. In this way, scarce resources are distributed to more efficient areas in the economy (Watts, 1992: 5-6).

The trading system in the world is mainly based on the concept of free trade. The free trade approach, which is one of the main arguments of the market economy, argues that the lack of intervention of states or the minimize the intervention of states in the trade between countries is essential. In the free trade system, where the market is not driven by state interventions, it is predicted that the inter-country division of labor will become more profitable, the potential national income of the countries will increase and a higher level of welfare will be achieved worldwide (Büyüktaşkın, 1997).

\section{Free Trade System and Protectionism}

Free trade system is a system where goods and services trade between countries is not blocked by states with any restrictions or interventions (Fouda, 2012: 351). Krugman (1983) and Bhagwati (2004) state that free trade is effective on employment increasing, poverty reduction, redistribution of income and economic growth. Solow (1956) also states that free trade will accelerate economic growth and development. Winters (2004) argues that minimizing barriers to free trade will increase overall factor productivity by increasing competition in imports.

Free trade policies based on the basic assumptions of the market economy are thus regarded as the most appropriate policies in the solution of the problems of development, stability and distribution. The countries' free trade policies are the best policies to increase world welfare; in that case, the obstacles to international trade are removed and every step towards free trade has an increasing effect on world welfare. In this respect, such policies are called "the first 
best policies". One of the most important assumptions of free trade policies is that there is no difference between private and social costs. However, this assumption is not actually like this most of the time. Because, in real life, there is a difference between private cost and social cost due to market failures such as the existence of monopolies, externalities, government interventions and trade diversifying competition in export markets. In order to eliminate or minimize the difference between the private and the social costs, the intervention instruments put constitute "the second best policy" (Seyidoğlu, 2003: 214-215). The second best policy in international trade was developed by Meade and generalized by Lipsey and Lancaster (Robertson, 1972: 18).

In essence, the free trade system allows the protectionist policies to be implemented within their own limits in order to maintain their existence. Protectionism is defined as an attempt by governments to impose restrictions on the exchange of goods and services with other countries (Osabuohien vd., 2014: 14). The objectives of the protectionist policies are, in principle, national security, economic development, protection of small industries, increasing employment, keeping real wages highly, improving trade volume and increasing international competitiveness (Abboushi, 2010: 387).

Within the scope of foreign trade policy, there are a number of tools used in the scope of the protectionist policies implemented in order to limit foreign trade as well as liberalization. Protectionism instruments can be grouped into two groups as tariff and tariff-like protectionism instruments and non-tariff barriers by their qualifications (Vural, 1999: 183). However, protectionism instruments have a number of effects on the public finance of countries. When considered in terms of these effects, it is possible to divide the instruments of protectionist policy into two groups as fiscally protectionism instruments (Engin, 1992: 82-93) and non-fiscally protectionism policy instruments. In this study, fiscally protectionism instruments have been taken into consideration. These instruments include anti-dumping duties, countervailing duties and safeguards that require fiscal liability.

\section{Literature Review}

When the literature about the study is examined, it has been observed that there are no studies on the factors affecting the use of fiscally protectionism instruments in the studies that can be achieved, and the current studies have been focused mainly on antidumping applications. According to the results obtained, developed countries used the anti-dumping duties for reasons such as political pressures, country interests, political disagreement and obtaining hegemon power except for fair trade purpose (Finger vd., 1982; Knetter \& Prusa, 2003; Aggarwal, 2004). Some studies have concluded that underdeveloped and developing countries use the antidumping duties for fair trade (Türkcan \& Dişbudak, 2005; Bown, 2008).

\section{Data Set, Method and Findings}

In the analysis to be carried out within the scope of the study, 16 countries that use mostly fiscally protectionism instruments are considered. These countries are Argentina, Australia, Brazil, Canada, Chile, China, European Union, India, Indonesia, Japan, Korea, Mexico, Russia, South Africa, Turkey and the United States. The aim of this study is to determine the factors affecting the use of fiscally protectionism instruments of WTO members by negative binomial regression analysis. In the study, as the dependent variable, the number of measures taken by the countries within the scope of anti-dumping duties, countervailing duties and safeguard 
measures are taken into consideration. As an independent variable, growth rate, the share of imports in GDP, the ratio of exports to imports, exchange rate and unemployment rate were taken. The analysis of the study was performed using Stata 13 package program. In the literature, no studies have been found about the factors affecting the use of fiscally protectionism instruments, and the current studies have focused mainly on antidumping applications. From this point of view, determining the factors affecting the use of fiscally protectionism instruments in total constitute the originality of the study. With this dimension, it is thought that the study will make a significant contribution to the literature.

As a result of the analysis, when the factors affecting the use of fiscally protectionism instruments are examined, independent variables are not statistically significant in Chile, Korea and Mexico. Apart from these countries, when the factors affecting the use of the fiscally protectionism instruments of high income countries are examined, it is seen that they do not use fiscally protectionism instruments for fair reasons but they use it because of their interests, political pressure and disagreements with other countries. In low and middle-income countries, when the factors affecting the use of fiscally protectionism instruments are examined, it is observed that they act with macroeconomic concerns in order to complete their economic development.

\section{Conclusion}

It is observed that the fiscally protectionism instruments which are allowed to be used in order to prevent unfair competition within the scope of WTO do not serve this purpose both in the scope of the study and in the literature. These instruments, most commonly used by developed countries, are used in line with national interests without valid ground. In order to prevent this situation and to make world trade more fair, the WTO should update the rules on the use of fiscally protectionism instruments and should not serve the interests of developed countries.

Developing countries should implement and develop protectionist strategies in order to adapt to rapidly developing conditions and to maintain competitive advantages against developed countries. Because the limited and necessary protectionism policy instrument do not disturb the functioning of the free trade system. On the contrary, this is an important issue in order to maintain the existence of free trade system. Therefore, limited and necessary protectionism policy instruments should be used fairly instead of protectionist practices aimed at disrupting the functioning of the market economy by causing unfair competition in international trade.

\section{References}

Abboushi, S. (2010). "Trade Protectionism: Reasons and Outcomes", An International Business Journal, Vol. 20(5), pp.384-394.

Aggarwal, A. (2004). "Macro Economic Determinants of Antidumping: A Comparative Analysis of Developed and Developing Countries", World Development, Vol. 32(6), pp.1943-1057.

Akalın, G. (2002). Türkiye'de Ekonomi - Politik Kriz ve Piyasa Ekonomisine Geçiş, Ankara, Akçağ Basım Yayım.

Bhagwati, J. (2004). In Defense of Globalization, New York, Oxford University Press.

Bown, C. P. (2008). "The WTO and Antidumping in Developing Countries", Economics \& Politics, Vol. 20(2), pp.255-288. 
Büyüktaşkın, Ş. (1997). Dünya Ticaret Sistemi (GATT, DTÖ ve Türkiye), http://www.senerbuyuktaskin. com/dunya-ticaret-sistemi-gatt-dunya-ticaret-orgutu-ve-turkiye/, (05.10.2017).

Engin, N. (1992). Uluslararası Ticarette Korumacı Eğilimler, İstanbul, íTO Yayın No: 1992-4.

Finger, J.M., Hall, H. K. \& Nelson, D. R. (1982). "The Political Economy of Administered Protection", The American Economic Review, Vol. 72(3), pp.452-466.

Fouda, R. A. N. (2012). "Protectionism and Free Trade: A Country's Glory or Doom?", International Journal of Trade, Economics and Finance, Vol. 3(5), pp.351-355.

Knetter, M. M. \& Prusa, T. J. (2003). “Macroeconomic Factors and Antidumping Filings: Evidence Form Four Countries", Journal of International Economics, 61, pp.1-17.

Krugman, P. (1983). "New Theories of Trade Among Industrial Countries", The American Economic Review, Vol. 73(2), pp.343-347.

Osabuohien, E., Efobi, U. R. \& Beecroft, I. (2014). "Free Trade, Protectionism and the Balance of Trade: New Empirical Insights", Beggar-Thy-Poor-Neighbour: Crisis-Era Protectionism and Developing Countries, (Ed.) Evenett, S. J., London, CEPR Press, pp.13-24.

Robertson, D. (1972). International Trade Policy, UK, Macmillan Education.

Seyidoğlu, H. (2003). Uluslararası Iktisat, 15. Baskı, İstanbul, Güzem Can Yayınları.

Solow, R. M. (1956). "A Contribution to the Theory of Economic Growth", The Quarterly Journal of Economics, Vol. 70(1), pp.65-94.

Türkcan, K. \& Dişbudak, C. (2005). “Antidamping Uygulamalarının Ekonometrik Analizi: Türkiye Örneği", iktisat, İşletme ve Finans, C. 20(233), ss.149-164.

Vural, i. Y. (1999). "Ithalatta Vergi Uygulamaları ve Korumacılık", Afyon Kocatepe Üniversitesi iktisadi ve Idari Bilimler Fakültesi Dergisi, C. 1(1), ss.183-202.

Watts, M. (1992). Piyasa Ekonomisi Nedir?, (Çev.) Köker, L., Ankara, Türk Demokrasi Vakfi.

Winters, L. A. (2004). "Trade Liberalisation And Economic Performance: An Overview", The Economic Journal, Vol. 114(2), pp.4-21. 